ISSN 1997-5902

\title{
Morphometric and agronomic characterization of 56 ginger landraces in Burkina Faso
}

\author{
Hervé NANDKANGRE ${ }^{* 1}$, Mahama OUEDRAOGO ${ }^{1}$, Mahamadou SAWADOGO², Souleymane BADO ${ }^{3}$, \\ Nerbéwendé SAWADOGO ${ }^{2}$, Adjima OUOBA ${ }^{1}$ and Moussa N. KONATE ${ }^{1}$ \\ ${ }^{1}$ Institut de l'Environnement et de Recherches Agricoles (INERA), Département de Productions Végétales, \\ Laboratoire de Génétique et de Biotechnologies Végétales, 04 BP 8645 Ouagadougou, Burkina Faso \\ ${ }^{2}$ Université de Ouagadougou, UFR-SVT, Département de Biologie et Ecologie Végétales, Equipe de Recherche en \\ Génétique et Amélioration des Plantes, Laboratoire Biosciences, 03 BP 7021 Ouagadougou 03, Burkina Faso \\ ${ }^{3}$ Plant Breeding and Genetics Laboratory, Department of Nuclear Sciences and Application, International Atomic \\ Energy Agency (IAEA), Vienna International Centre, PO Box 100, 1400 Vienna, Austria \\ ${ }^{*}$ Corresponding Author: Email: hervenankangre@yahoo.fr, Telephone: +226 72043062 / +26 76509086
}

Original submitted in on 19th April 2016. Published online at www.m.elewa.org on $30^{\text {th }}$ April 2016 http://dx.doi.org/10.4314/jab.v100i1.6

\section{ABSTRACT}

Objective: This study aims to characterize and assess the variability within the ginger accessions growing in Burkina Faso for morphometric and agronomic traits in order to identify appropriate strategies for the future breeding program.

Methodology and Results: The experiment was conducted with 56 accessions in Randomized Complete Block Design with four replications. Moderate diversity was observed for morphometric and agronomic characters. The linear Pearson's correlations between rhizome yield and rhizome weight per plant were significantly positives with the other characters, except days taken to maturity, which were negatives. Plant height was strongly associated with number of leaves, leaf length and rhizome width. The accessions gathering into two groups is not made according to their origin, but mainly on the basis of the characters such as rhizome yield, rhizome weight per plant, rhizome length, and plant height.

Conclusion and application: The ginger germplasm characterization is useful and has made it possible to understand the basic information for development of a scientific strategy for the efficient conservation of ginger. Strong associations between yield components and plant seize are important selection indices of rhizome yield and may be emphasized in the breeding programs for genetic improvement. Moreover, the model of clustering of the accessions can be used as a base for the choice of genotypes with interesting agro-morphological characteristics for the improvement of ginger productivity.

Keywords: Zingiber officinale Rosc, evaluation, variability, rhizome

\section{INTRODUCTION}

Ginger (Zingiber officinale Rosc.) is valuable plant all over the world as a spice in culinary preparations and for its medicinal properties (Jatoi et al., 2008; Pawar et al., 2010; Sivasothy et al.,
2011). Ginger is native to India and South East Asia (Preeti et al., 2008; Abdullah et al., 2010; Tokuhara et al., 2013). It is a perennial herbaceous grown as an annual crop. The plant habit is 
erected, has many fibrous roots, aerial shoot with leaves and has an underground stem called rhizome (Ravindran and Babu, 2005). Plant height can reach $90 \mathrm{~cm}$ when it is fully grown (Rashid et al., 2013), the leafy shoot is the pseudo-stem constituted of leaf sheath and bears 8-12 leaves (Vasala, 2001). The leaves are lanceolate to linear-lanceolate with $15-30 \mathrm{~cm}$ in length (Malhotra and Singh, 2003) and 2-3 cm width with sheathing bases (Mishra et al., 2012) which die off each year. Ginger is one of the species that is prone to sexual reproduction constraints, and mainly vegetatively propagated (Jatoi and Watanabe, 2013). Since ginger is vegetatively propagated, the genetic variability is very much narrow (Babu et al., 2013). However, the maximum variation within cultivated ginger was reported accessions grown in northern India (Parthasarathy et al., 2012). Many works undertaken on ginger were focused on the biochemical components (Geiger, 2005; Collen et al., 2012), in vitro tissue culture (Hiremath, 2006 ; Hossain et al., 2010; Ayenew et al., 2012; Villamor, 2012) and genetic diversity using molecular markers (Jatoi et al., 2006; Nair and Thomas, 2007 ; Lee et al., 2007). Ginger was introduced in

\section{MATERIAL AND METHODS}

Plant material: Ginger landraces used in this study were collected in South-west area of Burkina Faso. In Burkina Faso gingers is grown mainly in South-west and West areas (Figure 1). A total of 56 landraces were collected in following provinces: Comoé (three ecotypes), Léraba (16) and Kénédougou (37) highlighted in figure 1. Identities, numbers and origin of ecotypes were reported in table 1.

Study site: The experiment was carried out at Bérégadougou (10 $43^{\prime} 23.7^{\prime \prime}$ North and $004^{\circ} 44^{\prime} 47.1^{\prime \prime}$
Burkina Faso several decades ago, and is commonly called "Gnamankou". According to Nandkangré et al. (2015), in Burkina Faso, ginger production is limited on small surfaces, generally less than 1 ha, in spite of its many virtues. It is mainly grown by male farmers in the Sudanian agro-ecological zone (900 to $1300 \mathrm{~mm}$ of annual rainfall) and, is economically important for producers and traders. Except for the studies conducted by Nandkangré et al. (2015) on the characterization of production system, no research has been carried out on this specie in Burkina Faso. The literature pertaining to variability studies in gingers is mainly from India, China, Thailand and Malaysia (Jatoi and Watanabe, 2013). However, no such studies on gingers in Burkina Faso were reported. Thus, the variability structuring in ginger species in Burkina Faso is badly known. The knowledge of the variability structuring could allow not only its describing but also development of a conservation strategy for future breeding purposes. The current investigation aims to characterize the morphometric and agronomic variability of 56 ginger landraces collected in South-west area of Burkina Faso.

West) in the Cascades Region, located in the Sudanian phytogeographical zone of Burkina Faso. The climate is characterized by two seasons, a rainy season that lasts six months, from May to October. At this single rainy season, follow a dry season from December to April, initially fresh, then hot. Rainfall during 2015 crop season in Bérégadougou was $935 \mathrm{~mm}$ and the mean monthly minimum and maximum temperatures were $26.4^{\circ} \mathrm{C}$ (August) and $31.7^{\circ} \mathrm{C}$ (April), respectively 


\section{Nandkangre et al. J. Appl. Biosci. $2016 \quad$ Morphometric and agronomic characterization of 56 ginger landraces in Burkina Faso}

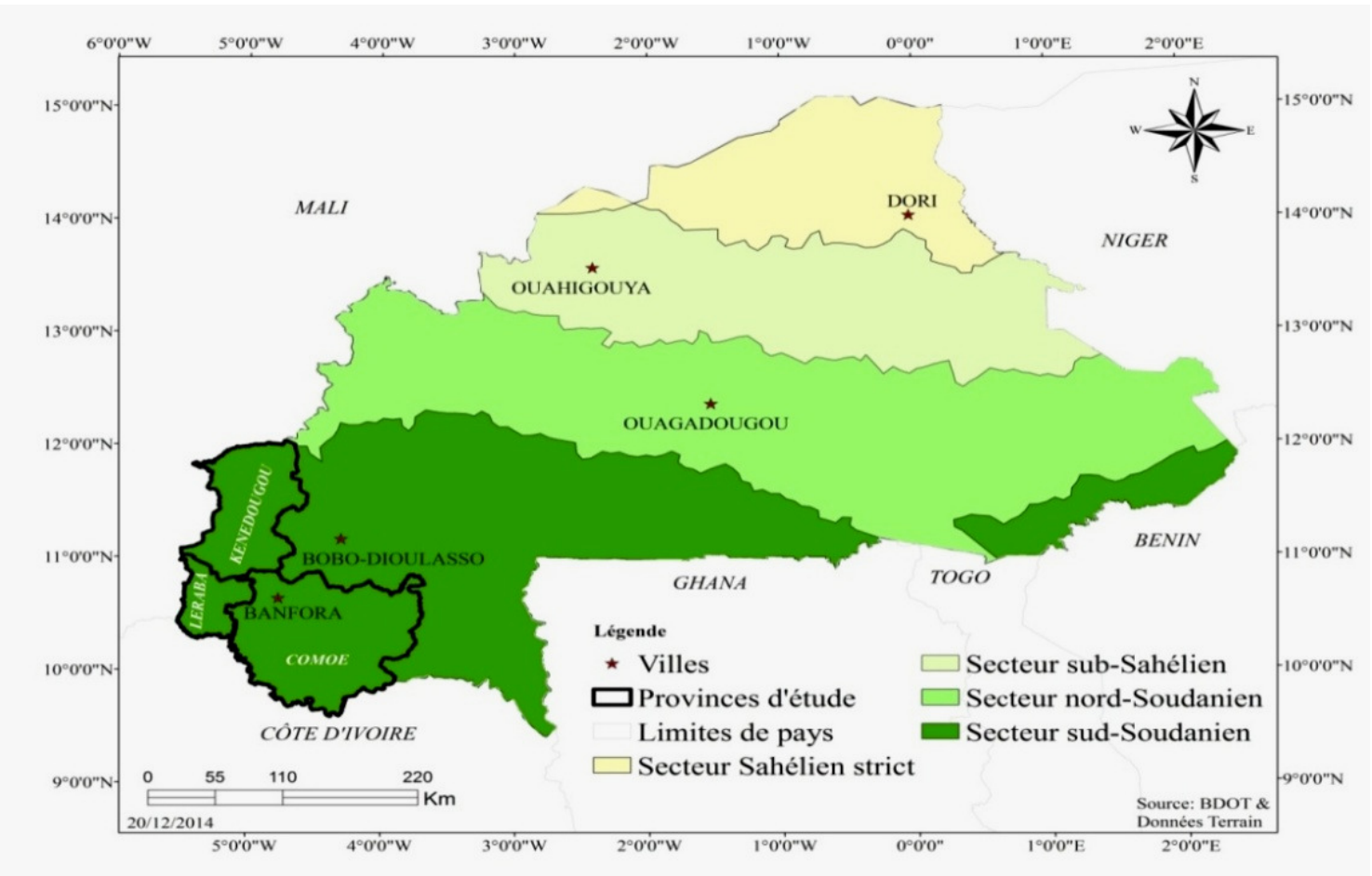

Fig 1: Area of ginger accessions collection

Table 1: Origin, identities and numbers of collected ginger accessions

\begin{tabular}{l|l}
\hline Accession No & Origin \\
\hline ZoC01; ZoC02; ZoC03 & Comoé \\
\hline ZoL04; ZoL05; ZoL06; ZoL07; ZoL08; ZoL09; ZoL10; ZoL11; ZoL12; ZoL13; ZoL14; ZoL15; & Léraba \\
ZoL16; ZoL17; ZoL58; ZoL60 & \\
\hline ZoK18; ZoK19; ZoK20; ZoK21; ZoK22; ZoK23; ZoK24; ZoK25; ZoK26; ZoK27; ZoK28; ZoK29; & \\
ZoK30; ZoK31; ZoK32; ZoK33; ZoK35; ZoK36; ZoK37; ZoK38; ZoK39; ZoK40; ZoK41; ZoK42; & Kénédougou \\
ZoK43; ZoK44; ZoK45; ZoK46; ZoK48; ZoK49; ZoK50; ZoK51; ZoK53; ZoK54; ZoK55; ZoK56; & \\
ZoK57 & \\
\hline
\end{tabular}

Experimental design and field management: Randomized Complete Blocks Design (RCBD) with four replications was used during the rainy season 2015. Each block was divided into four plots containing14 rows per plot; which correspond to 56 rows per replication. Each row was randomly assigned with one ecotype. The spacing was $30 \mathrm{~cm}$ between rows and 20 $\mathrm{cm}$ between holes. Plot size was $4.8 \times 1.4 \mathrm{~m}$ and distance between plots was $50 \mathrm{~cm}$. A distance of $1 \mathrm{~m}$ separated each replicate and replicate size was $10.1 \mathrm{~m}$ $x 3.3 \mathrm{~m}$. Eight pieces of rhizome seed, long from 3 to 5 $\mathrm{cm}$ each, with from two to three active buds were planted. The total surface of the experiment field was $163.62 \mathrm{~m}^{2}$. Fertilizer NPK and urea, at the rate of 150 $\mathrm{kg} \mathrm{ha}^{-1}$ and $100 \mathrm{~kg} \mathrm{ha}^{-1}$ respectively, were applied four and six weeks after planting. Manure (dung of cow) was also applied at the rate of $4.000 \mathrm{~kg} \mathrm{ha}^{-1}$.

Data collection and analysis: For data collection, three plants were randomly selected in each row. The accession ZoK51 was not considered during analyzes because it had less than three plants on some rows. A total of 19 characters qualitative and quantitative variables were recorded during different stages of plant development and after the harvest (Table 2). 
Table 2: Qualitative and quantative characters studied

\begin{tabular}{c|c|c|c}
\hline & & Code & Notation \\
\hline \multirow{4}{*}{$\begin{array}{c}\text { Qualitative } \\
\text { characters }\end{array}$} & Seedling vigour & Vig & - \\
& colour of the base of the seedling & COSdg & - \\
& presence of flower stalk & FIStk & - \\
& colour of flower & COFI & - \\
& rhizome colour & CORh & - \\
& Type of ramification & RhFing & - \\
\hline \multirow{4}{*}{ Quantitative } & rate of emerged shoots & Emg & $\%$ \\
& number of leaves per plant & NL/T & Number \\
& leaf length & LLen & $\mathrm{cm}$ \\
& leaf width & LWid & $\mathrm{cm}$ \\
& plant height & PIH & $\mathrm{cm}$ \\
& Tiller thickness & TilTh & $\mathrm{cm}$ \\
& number of tillers per plant & Til/P & $\mathrm{Number}$ \\
& days taken to maturity & Dm & days \\
& rhizome Length & RhL & $\mathrm{mm}$ \\
& rhizome width & RhWid & $\mathrm{mm}$ \\
& rhizome thickness & RhTh & $\mathrm{mm}$ \\
& rhizome weight per plant & RhW/P & $\mathrm{g}$ \\
& average yield & YLD & $\mathrm{g} \mathrm{m} \mathrm{m}^{-2}$ \\
\hline
\end{tabular}

Statistical analyses were carried out with 54 accessions. The landrace ZoC02 was not considered during analyses because it had agro morphologic characteristics very different than other ones that do not make it possible to appreciate exactly the variability within the collection. For data analyses, descriptive statistics with qualitative traits and Pearson correlation between the characters were performed using Statistica version 6 . Median values, minima, maxima, coefficients of variation and analysis of variance (ANOVA) for each

\section{RESULTS}

Agro morphological variability: Qualitative traits studied showed different variants except for colour of flower (COFI) and colour of rhizome (CORh) which are characterized by yellow-red and yellowish respectively (Table 3). Vigour of the seedlings (Vig) was very good for $63 \%$ of the accessions, $9.3 \%$ had low strength and $27.8 \%$ of the seedlings had fair vigour. The presence of flower stalk (FIStk) was observed for $53.7 \%$ of the accessions whereas $46.3 \%$ did not develop the flower stalk. The collection of ginger was characterized by two types of fingers of rhizome (RhFing), short fingers $(68.5 \%)$ and long fingers $(31.5 \%)$. Characters used in character were computed using Genstat V4.10.3. Associations between these characters were performed through to Pearson correlation at 5\%. Principal Component Analysis was performed in order to identify the characters, which are best represented. Cluster analysis for divergence among genotypes was performed using method of Ward with Statistica version 6 . The groups were then characterized through the factorial discriminating analysis.

analysis of variance and descriptive statistics to assess the ginger collection are listed in table 4 . The result of analysis of variance showed significant differences at $5 \%$ probability level for the characters such as rate of emerged shoots, numbers of leaves, leaf length, plant height, rhizome length and rhizome width. The coefficient of variation was high for rhizome weight per plant $(54.34 \%)$ and rhizome yield $(55.45 \%)$. On the other hand, low values of coefficient of variation were recorded for leaf width $(12.17 \%)$, leaf length $(12.19 \%)$ and tiller thickness $(11.90 \%)$. 
Table 3: Variation of qualitative characters

\begin{tabular}{l|c|c}
\hline Characters & Variants & Frequency (\%) \\
\hline \multirow{2}{*}{ Vig } & Very good & 63 \\
& Fair & 27.8 \\
& Not good & 9.3 \\
\hline \multirow{2}{*}{ FIStk } & Presence & 53.7 \\
& Absence & 46.3 \\
\hline COFI & Yellow-red & 100 \\
\hline CORh & Yellowish & 100 \\
\hline \multirow{2}{*}{ RhFing } & Short & 68.5 \\
& Long & 31.5 \\
\hline
\end{tabular}

Legend: Vig: seedling vigour; COSdlg: colour of the base of the seedling; FIStk: presence of flower stalk; COFI: colour of flower; CORh: rhizome colour; RhFing: Type of ramification

Table 4: Descriptive statistics and analysis of variance of fifty-five Z. officinale accessions grown in Burkina Faso

\begin{tabular}{l|c|c|c|c|c}
\hline Characters & Minimum & Maximum & CV (\%) & F of Fisher & F pr. \\
\hline Emg (\%) & 0 & 100 & 28.539 & $2.45^{* *}$ & $<.001$ \\
NL/T & 12.33 & 27 & 14.383 & $1.72^{* *}$ & 0.005 \\
LLen (cm) & 12.67 & 27.33 & 12.178 & $1.47^{* *}$ & 0.035 \\
LWid (cm) & 1.667 & 3.467 & 12.194 & 0.9 & 0.662 \\
TilTh (mm) & 4.273 & 8.497 & 11.904 & 1.4 & 0.057 \\
PIH (cm) & 39.67 & 116.7 & 19.448 & $1.86^{* *}$ & 0.002 \\
Til/P & 5 & 22.33 & 27.075 & 1.24 & 0.156 \\
Dm (days) & 155 & 192 & 4.8819 & 0.85 & 0.752 \\
RhL (mm) & 60 & 223.3 & 19.938 & $1.81^{* *}$ & 0.003 \\
RhWid (mm) & 19.74 & 74.81 & 22.788 & $1.5^{* *}$ & 0.03 \\
RhTh (mm) & 9.097 & 43.94 & 20.394 & 0.96 & 0.56 \\
RhW/P (g) & 5.833 & 295 & 54.344 & 1.19 & 0.211 \\
YLD (g m $\left.\mathbf{m}^{-2}\right)$ & 83.33 & 4143 & 55.454 & 1.24 & 0.156 \\
\hline
\end{tabular}

Legend:

Emg: rate of emerged shoots ; NL/P: number of leaves per plant; LLen: leaf length; LWid: leaf width; PIH: plant height; TilTh: Tiller thickness; Til/P: number of tillers; Dm: days taken to maturity; RhL: rhizome Length; RhWid: rhizome width; RhTh: rhizome thickness; RhW/P The rhizome weight per plant; YLD: average yield; ${ }^{* *}$ indicate significant difference at $5 \%$; ns: Not significant

Character associations: The Ginger accessions studied showed positive and negative correlations $(p=$ $5 \%$ ) among quantitative characters studied (Table 5). Rhizome yield and rhizome weight per plant had a positive and significant correlation with all the characters except, days taken to maturity, which had a negative correlation. In addition, days taken to maturity had a negative correlation with all the other characters. Highest positive correlation (0.887) was observed between rhizome yield and rhizome weight per plant.
High significant correlations $(r>0.60)$ among rhizome yield, rhizome weight per plant, numbers of leaves, leaf length and plant height were observed. Plant height showed an important correlation with rhizome length ( $r$ $=0.574)$, rhizome width $(r=0.663)$, leaf width $(r=$ $0.681)$ and tiller thickness $(r=0.623)$. Correlations between number of tiller were positive but not significant with tiller thickness $(r=0.251)$, rhizome width $(r=0.118)$ and rhizome thickness $(r=0.232)$. 
Table 5: Pearson correlation matrix for thirteen (13) characters in ginger accessions collection from Burkina Faso

\begin{tabular}{|c|c|c|c|c|c|c|c|c|c|c|c|c|}
\hline Variables & Emg (\%) & $\mathrm{NL} / \mathrm{T}$ & $\begin{array}{l}\text { LLen } \\
(\mathrm{cm})\end{array}$ & $\begin{array}{l}\text { Lwid } \\
(\mathrm{cm})\end{array}$ & $\begin{array}{l}\text { TilTh } \\
\text { (mm) }\end{array}$ & $\begin{array}{l}\text { PIH } \\
\text { (cm) }\end{array}$ & Til/P & $\begin{array}{c}\text { Dm } \\
\text { (days) }\end{array}$ & $\begin{array}{l}\text { RhL } \\
(\mathrm{mm})\end{array}$ & $\operatorname{RhWid}(\mathrm{mm})$ & $\begin{array}{l}\text { RhTh } \\
\text { (mm) }\end{array}$ & $\begin{array}{c}\text { RhW/P } \\
\text { (g) }\end{array}$ \\
\hline
\end{tabular}

\begin{tabular}{|c|c|c|c|c|c|c|c|c|c|c|c|c|}
\hline Emg (\%) & 1 & & & & & & & & & & & \\
\hline $\mathrm{NL} / \mathrm{T}$ & 0.253 & 1 & & & & & & & & & & \\
\hline LLen (cm) & 0.181 & $0.771^{* *}$ & 1 & & & & & & & & & \\
\hline Lwid (cm) & 0.078 & $0.727^{\star *}$ & $0.691^{* *}$ & 1 & & & & & & & & \\
\hline TilTh (mm) & -0.068 & $0.604^{* *}$ & $0.624^{* *}$ & $0.584^{\star *}$ & 1 & & & & & & & \\
\hline $\mathrm{PIH}(\mathrm{cm})$ & 0.15 & $0.814^{\star *}$ & $0.774^{\star *}$ & $0.681^{* *}$ & $0.623^{* *}$ & 1 & & & & & & \\
\hline Til/P & $0.324^{* *}$ & $0.381^{* *}$ & 0.450 ** & $0.340^{* *}$ & 0.251 & $0.490^{* *}$ & 1 & & & & & \\
\hline Dm (days) & -0.034 & $-0.304^{* *}$ & -0.241 & $-0.299^{\star *}$ & $-0.300^{\star *}$ & $-0.405^{\star *}$ & $-0.285^{\star *}$ & 1 & & & & \\
\hline $\mathrm{RhL}(\mathrm{mm})$ & 0.142 & $0.608^{* *}$ & $0.560^{* *}$ & $0.549^{* *}$ & $0.527^{* *}$ & $0.574^{* *}$ & $0.325^{\star *}$ & -0.213 & 1 & & & \\
\hline RhWid (mm) & 0.017 & $0.622^{* *}$ & $0.605^{* *}$ & $0.526^{\star *}$ & $0.333^{* *}$ & $0.663^{* *}$ & 0.118 & $-0.325^{* *}$ & $0.533^{* *}$ & 1 & & \\
\hline RhTh (mm) & 0.053 & $0.332^{\star *}$ & $0.492^{* *}$ & $0.382^{* *}$ & $0.303^{* *}$ & $0.405^{\star *}$ & 0.232 & -0.102 & $0.465^{\star *}$ & $0.472^{\star *}$ & 1 & \\
\hline RhW/P (g) & $0.308^{* *}$ & $0.613^{* *}$ & $0.637^{* *}$ & $0.428^{* *}$ & $0.434^{* *}$ & $0.730^{* *}$ & $0.489^{* *}$ & -0.202 & $0.519^{* *}$ & $0.579 * *$ & $0.492^{* *}$ & 1 \\
\hline YLD $\left(\mathrm{g} \mathrm{m}^{-2}\right)$ & $0.355^{* *}$ & $0.705^{\star *}$ & $0.751^{* *}$ & $0.475^{* *}$ & $0.493^{* *}$ & $0.748^{* *}$ & $0.487^{* *}$ & -0.207 & $0.524^{* *}$ & $0.556^{\star *}$ & $0.462^{* *}$ & $0.887^{* *}$ \\
\hline
\end{tabular}

Legend:

Emg: rate of emerged shoots ; NL/P: number of leaves per plant; LLen: leaf length; LWid: leaf width; PIH: plant height; TilTh: Tiller thickness; Til/P: number of tillers per plant; Dm: days taken to maturity; RhL: rhizome Length; RhWid: rhizome width; RhTh: rhizome thickness; RhW/P: rhizome weight per plant; YLD: average yield; ${ }^{* *}$ Correlation is significant at the 0.05 level. 
Principal components analysis: Analysis in principal components exhibited the variability within the ginger germplasm. The cumulative values of the variance of the first three principal components (F1, F2 and F3) for the 13 quantitative traits were $69.938 \%$, with Eigen values ranging between 1.046 and 6.683 (Table 6). Principal component F1 had an Eigen value 6.683 and contributed for $51.412 \%$ of the variation of the characters. This principal component (F1) is associated negatively with all the characters except, days to maturity (figure 2). Principal components F2 and F3 had respective Eigen values 1.361 and 1.040, accounted for $10.472 \%$ and $8.052 \%$ to the total variation and were associated positively with rate of emerged shoots and negatively to day taken to maturity, respectively (figure 3). The Bartlett's test of sphericity has given a critical value 99.617 with $p$-value $<0.0001$ at $5 \%$ level of probability.

Table 6: Coordinate of 13 traits and the contribution to the total variability of the Z. officinale accessions collection

\begin{tabular}{lccc}
\hline \multirow{2}{*}{ Characters } & \multicolumn{3}{c}{ Principal components } \\
\cline { 2 - 4 } & F1 & F2 & F3 \\
\hline Emg (\%) & -0.249 & 0.809 & 0.053 \\
NL/T & -0.871 & -0.040 & 0.086 \\
LLen $(\mathbf{c m})$ & -0.879 & -0.036 & -0.050 \\
LWid (cm) & -0.761 & -0.259 & 0.1273 \\
TilTh (mm) & -0.684 & -0.347 & 0.1710 \\
PIH (cm) & -0.907 & -0.052 & 0.1197 \\
Til/P & -0.539 & 0.4782 & 0.3468 \\
Dm (days) & 0.392 & 0.1724 & -0.692 \\
RhL (mm) & -0.727 & -0.119 & -0.134 \\
RhW (mm) & -0.722 & -0.261 & -0.216 \\
RhTh (mm) & -0.570 & -0.074 & -0.499 \\
RhW/P (g) & -0.815 & 0.2865 & -0.196 \\
YLD (g m $\left.{ }^{-2}\right)$ & -0.854 & 0.2885 & -0.148 \\
\hline Eigen value & 6.683 & 1.361 & 1.046 \\
\% variance & 51.412 & 10.472 & 8.052 \\
\% cumulative & 51.413 & 61.886 & 69.938 \\
\hline Len:
\end{tabular}

Legend:

Emg: rate of emerged shoots; NL/P: number of leaves per plant; LLen: leaf length; LWid: leaf width; PIH: plant height; TilTh: Tiller thickness; Til/P: number of tillers; Dm: days taken to maturity; RhL: rhizome Length; RhWid: rhizome width; RhTh: rhizome thickness; RhW/P The rhizome weight per plant; YLD: average yield 


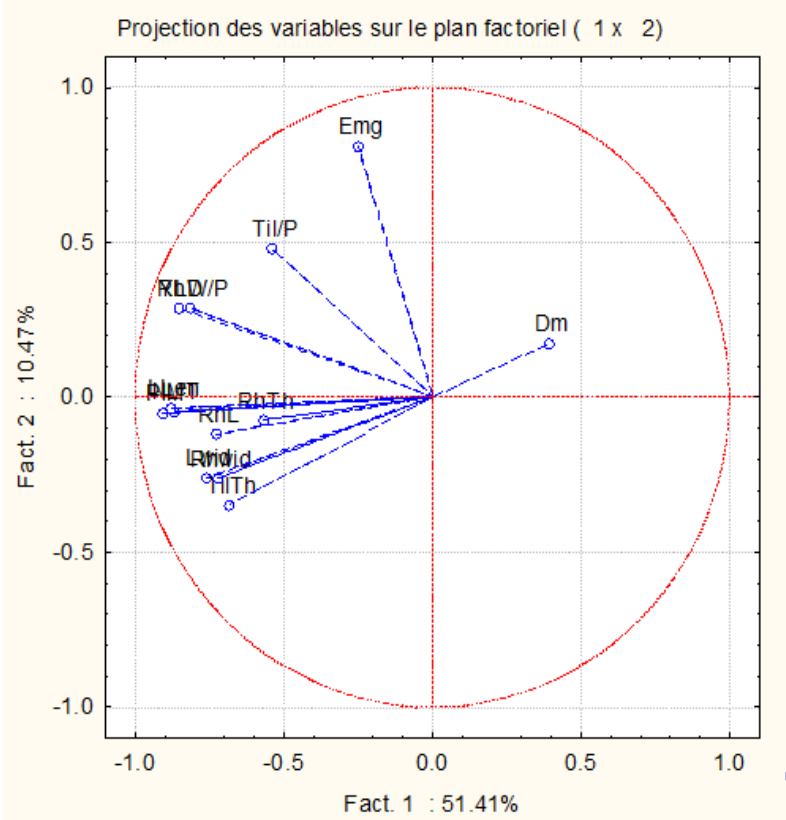

Figure 2: Distribution of the characters on the two first axes of the principal components

Structure of the variability: The dendrogram resulting from the Agglomerative Hierarchical Clustering set out with a truncation on the level of inertia 150 (Figure 4). Cluster analysis performed on weighted averages Euclidean distance highlighted two groups of the ginger accessions, based on the characters such as rhizome yield, rhizome weight per plant, rhizome length,

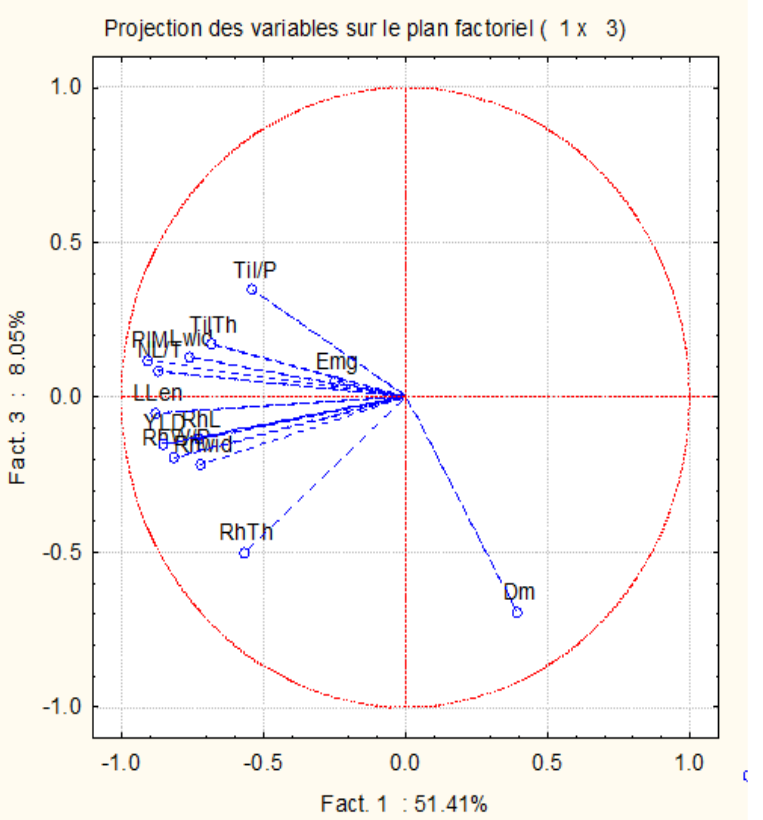

Figure 3: Distribution of the characters on the axes $1 / 3$ of the principal components.

rhizome width, plant height and rate of emerged shoots. The first group is formed by 31 accessions collected from the three provinces. In this group, 20 collected from Kénédougou, 10 from Léraba and one accession from Comoé. Whereas, the second group is formed by 23 accessions from which 16 were from Kénédougou, six from Léraba and only one from Comoé.

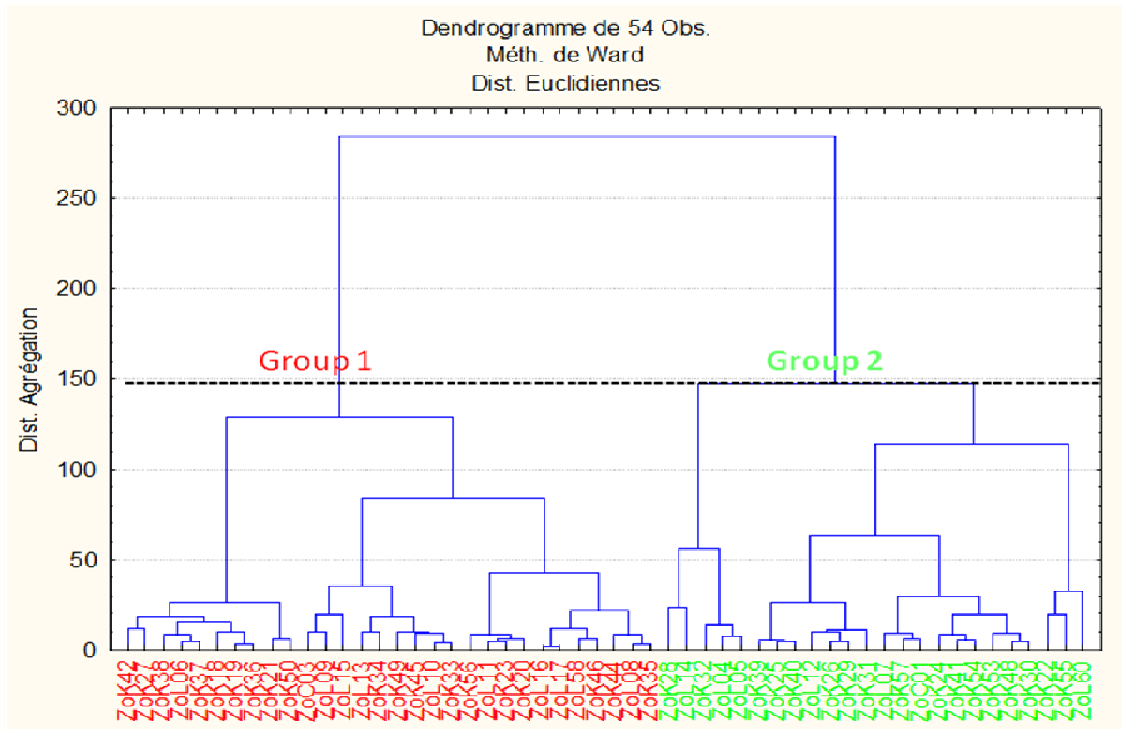

Figure 4: Dendrogram showing the clustering pattern in Z. officinale accessions based on morphometric and agronomic traits 
The factorial discriminant analysis showed two distinct groups (Figure 5). The squares of the distances of Mahalanobis resulting from the discriminant analysis showed that the two groups differ significantly between them at $5 \%$ level of probability. The distance between the two groups is 7.209 with a p-value $<0.0001$. In addition, the result of the test of Lambda de Wilks has given a critical value 1.975 with $p$-value $<0.0001$ at $5 \%$ level of probability. These results are confirmed by the analysis of variance realized with the discriminating characters (Table 7)

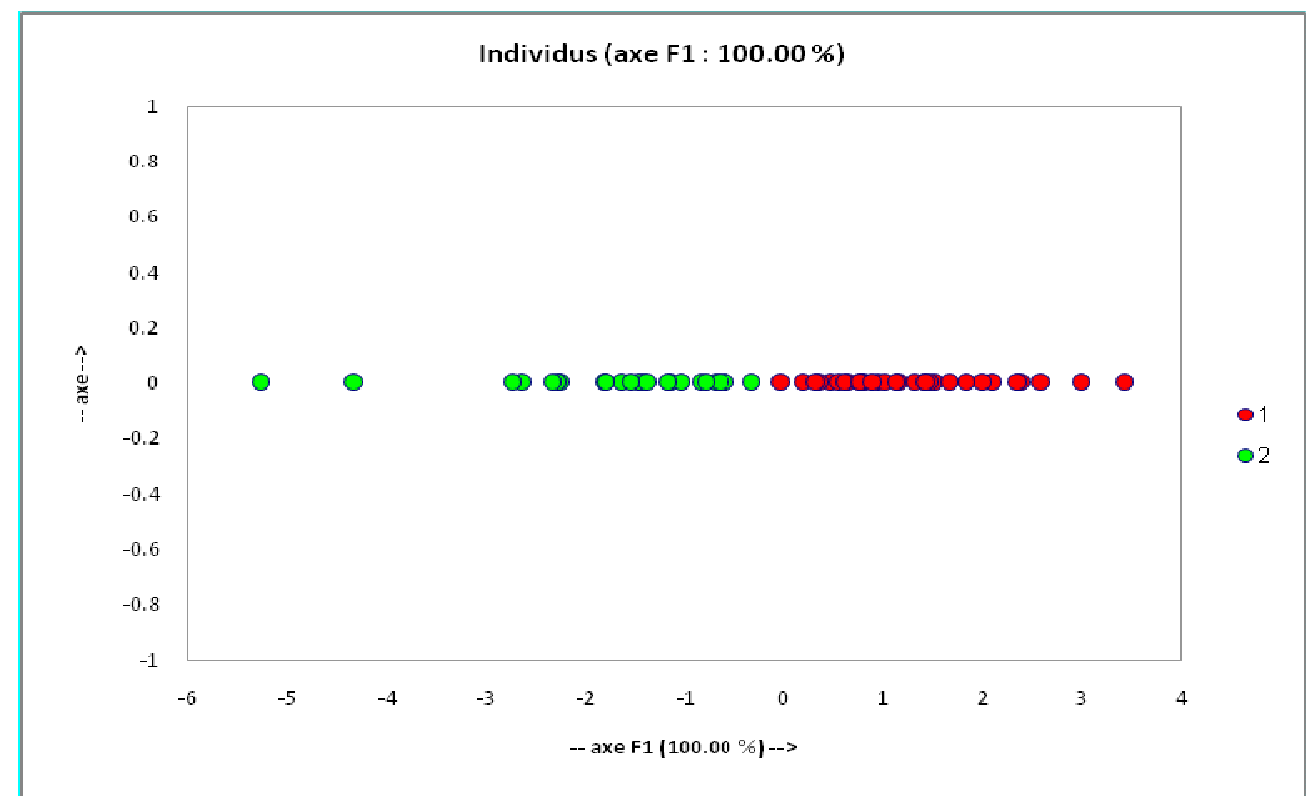

Figure 5: Discriminant analysis performed on axes F1 on the 2 classes obtained through hierarchical clustering

Tableau 7: Average performance of ginger groups in South-west area of Burkina Faso

\begin{tabular}{lccc}
\hline Characters & Group 1 & Group 2 & F \\
\hline Emg (\%) & 79.93 & 62.77 & $32.11^{* *}$ \\
PIH $(\mathbf{c m})$ & 82.34 & 77.01 & $7.43^{* *}$ \\
RhL $(\mathbf{m m})$ & 145.34 & 126.99 & $25.67^{* *}$ \\
RhWid $(\mathbf{m m})$ & 45.65 & 41.97 & $15.21^{* *}$ \\
RhW/P $(\mathbf{g})$ & 98.13 & 75.40 & $7.03^{* *}$ \\
YLD $\left(\mathrm{g} \mathrm{m}^{-2}\right)$ & 13630 & 10590 & $16.12^{* *}$ \\
\hline
\end{tabular}

Legend:

Emg: rate of emerged shoots; PIH: plant height; RhL: rhizome Length; RhWid: rhizome width; RhW/P: rhizome weight per plant; YLD: average yield

\section{DISCUSSION}

Not all the accessions developed a floral stalk. More than $51 \%$ of the accessions carried a floral stalk. According to Ravindran et al. (2005) flowering is reported on gingers from South China, but not from North China and Nigeria. In general, ginger does not flower under subtropical or subtemperate climatic conditions. The appearance of the floral stalk could result of interaction genotype-environment (Ravindran et al., 2005). The ecotypes that flowered had a yellow- red colour. Parthasarathy et al. (2012) reported that ginger flowers vary in their labellem shape and colour depending on the genotype. The agro-climatic conditions have a great influence on expression of morphological characters (Peter et al., 2007). The rhizome colour was yellowish for all the accessions assessed in the South-west and West areas of Burkina Faso. However, Ravindran et al. (2005) reported that in addition to the yellowish ginger, there is red ginger in 
Malaysia and black ginger in Nigeria. The type of fingers of the rhizome observed is an important criterion in the choice of the ginger cultivar in Burkina Faso. Producers prefer ginger varieties with short fingers because these cultivars are most pungent than the long ones. The 13 quantitative traits studied revealed the existence of moderate genetic variability among ginger accessions grown in Burkina Faso. Analysis of variance exhibited the existence of some discriminatory characters such as number of leaves per tiller, leaf length, plant height, rhizome length and rhizome width. Whereas Aragaw et al. (2011) and Ravishanker et al. (2013) observed an important genetic variability within ginger accessions from Ethiopia and India, respectively. Ravindran et al. (2005) reported that variability tends to be limited within the cultivars resulting from the same area compared to the ones growing in geographically distant location. That could be explain the moderate variability observed in our study, because, the accessions used have been collected in three province very close and located in South-west area of Burkina Faso. Genetic variability could be exploited at ends of selection to improve the studied traits in order to support the expression of the rhizome yield. It is necessary to collect more accessions and multiply them each year in order to conserve ginger genetic resources. Pearson correlation matrix revealed several positive associations between the characters. However, negative associations between days taken to maturity and all the other characters and between rate of emerged shoots and tillers thickness was observed. Contrary to observations of Jatoi and Watanabe (2013), this showed negative correlation between rhizome weight and leaf length with ginger landraces. The association among different traits is an important and useful feature, which helps to identify various characters that can be potentially focused for further consideration in crop improvement (Jatoi and Watanabe, 2013). Our study showed that rhizome yield had strong correlations with rhizome weight per plant, follow by leaf length, plant height and number of leaves per tiller. Most characters are above observations therefore can be used easily as an indicator of the rhizome yield which is an important trait of ginger breeding as pungent trait of the rhizome. This indicates that direct selections toward these traits are possible for the improvement of ginger yield. According to Sasikumar et al. (1992), rhizome yield had positive and significant correlations with plant height, leaf number, tiller number and leaf dimensions. In addition,
Ravishanker et al. (2013) showed that yield per plant had positive and significant associations with plant height; but a negative correlation was observed with tiller thickness. In the present study, rhizome weight per plant, plant height, leaf length, number of leaves and rhizome length appeared to be of greatest importance as these influence rhizome yield. Maximum variation exhibited by the principal component F1 based principally on the characters plant height, leaves length, number of leaves, rhizome weight per plant and rhizome yield. The variance value $(51.41 \%)$ is very high than those obtained by Aragaw et al. (2011) at Tepi $(33.59 \%)$, where, maximum variation showed by the first principal component was based on the traits such as, leaf length, plant height, rhizome width, days taken to maturity, and at Bahir Dar (23.32\%), by rhizome yield. This observed difference could be explained by the different origins of the plant material and the numbers of accessions used for the characterization. Agglomerative Hierarchical Clustering (AHC) showed two groups containing respectively 31 and 21 accessions in group 1 and group 2. The clusters are mainly based on the characters such as rhizome yield, rhizome weight per plant, rhizome, rhizome width and plant height. Ravindran et al. (2005) obtained three groups based on the rhizome yield, tillers number per plant and plant height with ecotypes grown in Japan. Singh et al. (1999) also obtained three groups with 18 ecotypes, based on yield and others quality traits such as oleoresin content and fibre density of the rhizome. Cluster analysis made by Jatoi and Watanabe (2013) assigned 19 ginger accessions into three groups also. The Clustering pattern of two groups is slightly similar to the findings of Ravindran et al. (2005) with ginger ecotypes grown in Japan. The ginger types are classified according to plant stature and yield into small-sized plants with a small rhizome (Group 2), and large-sized plants with larger rhizomes (Group 1). The accession gathering is not made according from their acquisition source. The two groups contained accessions from different province. The proximity of the provinces and the relative link of the producers would support the exchanges of genetic material. This would explain why the accessions form composite groups. The model of regrouping of the accessions can be used as a base for the choice of genotypes with interesting agro-morphological traits (Ravindran et al., 2005) for the improvement of ginger productivity, because producers' and consumers criteria of gingers adoption 
in Burkina Faso are mainly focused on rhizome yield CONCLUSION

Ginger germplasm from Burkina Faso shows moderate genetic variability in the qualitative and quantitative traits studied. Several associations are positive and several significant correlations have been observed between the characters related to yield. Principal component analysis shows that Clustering of the accessions was based on yield components and plant

\section{ACKNOWLEDGEMENTS}

We appreciate the financial support of the FONRID in this work.

\section{REFERENCES}

Abdullah S, Abidin SAZ, Murad NA, Makpol S, Ngah WZW, Yusof YAM, 2010. Ginger extract (Zingiber officinale) triggers apoptosis and G0/G1 cells arrest in HCT 116 and HT 29 colon cancer cell lines. Afr. J. Biochem. Res. 4 (4): 134 - 142.

Aragaw M, Allamerew S, Michael GH, and Tesfaye A, 2011. Variability of ginger (Zingiber officinale) accessions for morphological and some quality traits in Ethiopia. Int. J. Agri. Res., ISSN 1816 - 4898 / DOI: 10.3223/ijar.

Babu KN, Suraby EJ, Cissin J, Minoo D, Pradeepkumar T, Parthasarathy VA, Peter KV, 2013. Status of transgenics in Indian spices. J. Tropical Agri. 51 (1-2): 1-14.

Geiger JL, 2005. The essential oil of ginger, Zingiber officinale, and anaesthesia. The International Journal of Aromatherapy 15: 7-14.

Hiremath RC, 2006. Micropropagation of ginger (Zingiber officinale [Rosc.]). Thesis, Master of Science. University of Agricultural Sciences. Dharwad, $40 \mathrm{p}$.

Hossain A, Hassan L, Patwary AK, Mia MS, Ahmad SD, Shah AH, Batool F, 2010. Establishment of a suitable and reproducible protocol for in vitro regeneration of ginger (Zingiber officinale Roscoe). Pak. J. Bot. 42 (2): 1065-1074.

Jatoi SA, Kikuchi A, Mimura M, Yi SS, Watanabe N, 2008. Relationship of Zingiber species and genetic variability assessment in ginger $(Z$. officinale) accessions from ex-situ genebank, on-farm and rural markets. Breed. Sci. 58: 261-270.

Jatoi SA, Kikuchi A, Yi SS, Naing KW, Yamanaka S, Watanabe JA, Watanabe KN, 2006. Use of rice SSR markers as RAPD markers for and pungency.

height. Selection for ginger improvement could be based on rhizome weight per plant, plant height and rhizome length, but the rate of emerged shoots will also be rewarding for yield improvement For further characterization, using of molecular markers can be performed to exhibit the tangible genetic diversity within ginger cultivars of Burkina Faso. genetic diversity analysis in Zingiberaceae. Breed. Sci. 56: 107-111.

Jatoi SA. and Watanabe KN, 2013. Diversity analysis and relationships among ginger landraces. Pak. J. Bot. 45 (4): 1203-1214.

Lee SY, Fai WK, Zakaria M, Ibrahim H, Othman RY, Gwag JG, Rao VR, Park YJ, 2007. Characterization of polymorphic microsatellite markers, isolated from ginger ( $Z$. officinale Rosc.). Mol. Ecol. Notes 7:1009-1011.

Malhotra S. and Singh AP, 2003. Medecinal properties of ginger (Zingiber officinale Rosc.). Natiural Product reliance 2 (6): 296-301.

Mishra RK, Kumar A, Kumar A, 2012., Pharmacological Activity of Zingiber officinale. International J. Pharm. Chem. Biol. Sci.1 (3): 1422-1427.

Nair RA. and Thomas G, 2007. Isolation, characterization and expression studies of resistance gene candidates (RGCs) from Zingiber spp. Theor. Appl. Genet. 116:123134.

Nandkangre H, Ouedraogo M, Sawadogo M, 2015. Caractérisation du système de production du gingembre (Zingiber officinale Rosc.) au Burkina Faso: Potentialités, contraintes et perspectives. Int. J. Biol. Chim. Sci. 9 (2): 861873.

Parthasarathy VA, Srinivasan V, Nair RR, John ZT, Kumar A, Prasath D. 2012. Ginger: Botany and Horticulture. Indian Institute of Spices Research Indian Council of Agricultural Research. Calicut, Kerala, India. 388p.

Pawar N, Pai S, Nimbalkar M, Kolar F, Dixit G, 2010. Induction of chlorophyll mutants in Zingiber officinale Roscoe by Gamma Rays and EMS. Em. J. Food Agri. 22 (5): 406-411. 
Peter KV, Ravindran PN, Babu KN, Divakaran M, 2007. Breeding of Spice Crops (Black Pepper, Cardamom, Ginger and Turmeric). Horticulture, Vegetable Science (Vegetables,

Spice Crops). Tubers and

http://nsdl.niscair.res.in//sspui/bitstream/123456 789/471/1/revised\%20Breeding\%20of\%20spic es.pdf. Accessed on 24 March 2015.

Preeti C, Dnyaneshwar W, Kalpana J, Bhushan P, 2008. Development of SCAR (sequencecharacterized amplified region) markers as a complementary tool for identification of ginger (Zingiber officinale Roscoe) from crude drugs and multicomponent formulations. Biotechnol. Appl. Biochem. 50: 61-69.

Rashid K, Daran ABM, Nezhadahmadi A, Zainoldin KHB, Azhar S, Efzueni S, 2013. The effect of using gamma rays on morphological characteristics of ginger (Zingiber officinale) plants. Life Sci. J. 10 (1): 1538-1544.

Ravindran PN. and Babu KN, 2005. Introduction. Pp. 114 In P.N. Ravindran and K.N. Babu. eds. Medicinal and aromatic plants Industrial profiles: Ginger, the genus Zingiber. CRC Press. Washington DC.

Ravindran PN, Babu KN, Shiva KN, 2005. Botany and Crop Improvement of Ginger. Pp. 15-85 In
P.N. Ravindran and K.N. Babu. eds. Medicinal and aromatic plants Industrial profiles: Ginger, the genus Zingiber. CRC Press. Washington DC.

Sasikumar B, Babu KN, Abraham J, Ravindran PN, 1992. Variability, correlation and path analysis in ginger germplasm. Indian J. Genet., 52(4): 428-431.

Sivasothy $Y$, Chong WK, Hamid A, Eldeen IM, Sulaiman SF, Awang K, 2011. Essential oils of Zingiber officinale var. rubrum Theilade and their antibacterial activities. Food Chem.124: 514-517.

Tokuhara D, Shimada T, Asami A, Takahashi A, Kobayashi H, Saimaru H, Aburada M, 2013. Pharmacokinetics of 6-shogal, a pungent ingredient of Zingiberis Rhizoma, and the antiinflammatory activity of its metabolite, 6paradol. J. Trad. Med. 30: 199-205.

Vasala PA, 2001. Ginger. Pp. 195-205 In K.V. PETER. eds. Handbook of herbs and spices. CRC Press. Abington, Cambridge, England.

Villamor CC, 2012. Micropropagation techniques for ginger, Zingiber officinale Rosc., An important medicinal plant. E-Intern. Sci. Res. J. 4 (3): 241-249. 